\title{
Researching Together and Improving Practice Outcomes
}

\author{
Marjorie A. Bowman, MD, MPA, and Anne Victoria Neale, PhD, MPH
}

In this issue, the Journal of the American Board of Family Medicine brings news about research by family physicians, health services research on getting physicians into rural areas, the causes of hospital readmissions of family medicine inpatients, international medical graduates in family medicine, using collaborations to improve office practice, auriculotherapy for smoking cessation, and physician opinions about medical marijuana, plus more! (J Am Board Fam Med 2013;26:1-3.)

\section{Research by Family Physicians, Often in Collaborations}

Voorhees et $\mathrm{al}^{1}$ report that few family physicians spend much time doing research. Yet our field sorely needs research that advances our care of patients, and family physicians bring a unique perspective specifically to do the most informative research. This article highlights a primary reason for the existence of the Fournal of the American Board of Family Medicine ( $7 A B F M$ ) - and for our own desires to edit this journal. We urge you to be a part of the solution. We need the support of all family physicians and family medicine faculty to conduct research of the nexus of primary care: diagnosing and treating undifferentiated symptoms, the person with multiple problems, and the problems that mix mental and classic organic causes, which comprises much of what we see in our clinical practice. One important way family physicians can participate and support primary care research is to join one of the many practice-based research networks (PBRNs). If you are interested in learning more, see the PBRN web pages supported by the US Agency for Health care Research and Quality at http://pbrn. ahrq.gov.

As an example of family physicians providing data through a PBRN, the report by Lawler et $\mathrm{al}^{2}$ is impressive. To ascertain the association of having a confidant with the chances of dying, this group of

From the American Board of Family Medicine, Lexington, $\mathrm{KY}$.

Funding: none.

Conflict of interest: The authors are editors of the JABFM. physicians identified and followed a cohort of patients older than age 65 for up to almost 12 years; $40 \%$ of the patients died by the end of the study period. Is having a confidant important, or is it a surrogate measure of having a spouse?

In another kind of research through collaborating practices, Meyer et $\mathrm{al}^{3}$ report on the Improving Performance in Practice initiative, in which a residency practice successfully implemented quality improvement measures. The $7 A B F M$ is particularly interested in team and patient-centered medical home projects that inform how outcomes can be improved in practice, which is a tough juggernaut, and one that has proven quite elusive. The article provides information about how this group made practice improvements with the assistance of biweekly meetings of learning teams from 6 counties plus a quality improvement consultant. Of note, improvement occurred primarily in areas that could reflect an improvement in documentation.

Appiah et $\mathrm{al}^{4}$ provide information gathered from discussion groups about the challenges reported when trying to implement diabetes guidelines. The groups' ideas provide us with new insights. While trying to improve practice outcomes, physicians continue to get requests for multiple preauthorizations, many of which seem unnecessary. Morely et $\mathrm{al}^{5}$ note that the cost of doing prior authorization for tests, medications, and other clinical services was in the range of $\$ 3000$ per full-time-equivalent physician per year in 12 primary care practices. They used data collected at the time of the event, which is a method better than that used previously to determine the cost. These numbers are likely to 
vary by type of practice and patient insurance, but even $\$ 3000$ per doctor is significant. Opportunity costs were not truly accounted for with this method. Furthermore, the cost of the sense of burden, that is, stress or anger, is certainly underestimated-burnout creates much havoc!

\section{Workforce: Getting Well-Trained Family Doctors Where They Are Needed}

Rural America badly needs family physicians. Rabinowitz et al ${ }^{6}$ previously reported a highly successful program that placed family physicians into rural environments. The current report also shows that the retention rate is high and persists even 20 to 25 years after the rural physician has graduated. This is a major success that should be replicated elsewhere for the sake of improving health in rural America.

We have 2 articles related to international medical graduates. First, Dickson et $\mathrm{al}^{7}$ find that, compared with US medical graduates, international medical graduates are more likely to report more experience and comfort with procedures associated with inpatient care. Conversely, US medical graduates report more experience and comfort with a number of ambulatory procedures. This is consistent with what we know and understand about the type of medical training received by the respective groups. In addition, Falcone and Middleton ${ }^{8}$ show us that in recent years, international medical graduates also had, on average, lower rates of passing the American Board of Family Medicine initial and recertification examinations. Both of these articles individually and together reinforce the need to tailor residency education to individual needs.

\section{Clinical Potpourri}

Using a specific method incorporating an ovulatory monitoring device, Bouchard et $\mathrm{al}^{9}$ provide a program to help postpartum breastfeeding women avoid pregnancy at the cusp of ovulation after amenorrhea. For couples using natural family planning, this could be quite helpful. Excellent use of the method led to low pregnancy rates (only 2 at 12 months) but found higher rates of pregnancy when the program was not used as recommended.

Herpes zoster is common, yet many patients are unaware. In the primary care clinics described here, there were unexplained significant differences in reported incidence of the disease and knowledge of the vaccine by race. ${ }^{10}$ Both the racial differences and the lack of knowledge bear consideration.

How do family physicians feel about medical marijuana? Kondrad and Reid ${ }^{11}$ report data from Colorado, which has legalized the medical use of marijuana with a prescription. They found that the largest areas of agreement was the need for more education and the risks involved. Many family physicians were not convinced that marijuana was medically useful.

We keep looking for low-risk methods to help patients with smoking cessation, and auriculotherapy (electrical stimulation of the ear) is an alternative therapy that seems safe. Some preliminary studies have suggested its efficacy. Carney et $\mathrm{al}^{12}$ report a negative, adequately powered randomized, placebo-controlled trial of auriculotherapy. So much for that good idea!

Garrison et $\mathrm{al}^{13}$ examined factors associated with readmissions to a family medicine inpatient service; previous research has not been specific in relating to typical family medicine patients. Do you think the factors are the same or different from those noted by other authors? Read more to find the answer.

Higgins et $\mathrm{al}^{14}$ add a review of another inpatient entity to be aware of: peripartum coronary artery dissection as a cause of myocardial infarctions. Robinson ${ }^{15}$ shares a warm and insightful memory of his deceased father-a family physician-and what he learned from him.

We will publish 2 theme issues in 2013. First, we will present a "Community of Solution" special issue that highlights articles reporting partnerships with community-based organizations to address health issues. In addition, our eighth annual practice-based research theme issue will highlight primary care research conducted in the practice setting.

\section{References}

1. Voorhees JR, Xierali IM, Bazemore AW, Phillips RL Jr, Jaén CR, Puffer JC. A small percentage of family physicians report time devoted to research. J Am Board Fam Med 2013;26:7-8.

2. Lawler FH, Mold JW, McCarthy LH. Do older people benefit from having a confidant? An Oklahoma Physicians Resource/Research Network (OKPRN) study. J Am Board Fam Med 2013;26:9-15.

3. Meyer AA, Donahue KE, Batish S, et al. Patient care outcomes of the SEAHEC Improving Performance 
in Practice (IPIP) experience. J Am Board Fam Med 2013;26:16-23.

4. Appiah B, Hong Y, Ory MG, et al. Practicing evidence-based diabetes self-management in primary care: challenges and opportunities. J Am Board Fam Med 2013;26:90-2.

5. Morley CP, Badolato DJ, Hickner J, Epling JW. The impact of prior authorization requirements on primary care physicians' offices: report of two parallel network studies. J Am Board Fam Med 2013;26: 93-5.

6. Rabinowitz HK, Diamond JJ, Markham FW, Santana AJ. Retention of rural family physicians after 20-25 years: outcomes of a comprehensive medical school rural program. J Am Board Fam Med 2013; 26:24-7.

7. Dickson GM, Chesser AK, Keene Woods N, Krug NR, Kellerman RD. Self-reported ability to perform procedures: a comparison of allopathic and international medical school graduates. J Am Board Fam Med 2013;26:28-34.

8. Falcone JL, Middleton DB. Performance on the American Board of Family Medicine certification examination by country of medical training. J Am Board Fam Med 2013;26:78-81.
9. Bouchard T, Fehring RJ, Schneider M. Efficacy of a new postpartum protocol for avoiding pregnancy. J Am Board Fam Med 2013;26:35-44.

10. Hayes S, Joon Lee T, Cummings DM, et al. Herpes zoster knowledge, prevalence, and vaccination rate by race. J Am Board Fam Med 2013;26:45-51.

11. Kondrad E, Reid A. Colorado family physicians' attitudes toward medical marijuana. J Am Board Fam Med 2013;26:52-60.

12. Carney RM, Steinmeyer B, Ditson G, Hill N, ZeeCheng J. The efficacy of auriculotherapy for smoking cessation: a randomized, placebo controlled trial. J Am Board Fam Med 2013;26:61-70.

13. Garrison GM, Mansukhani MP, Bohn B. Predictors of 30-day readmission in hospitalized family medicine patients. J Am Board Fam Med 2013;26:71-7.

14. Higgins GL III, Borofsky JS, Irish CB, Cochran TS, Strout TD. Spontaneous peripartum coronary artery dissection presentation and outcome. J Am Board Fam Med 2013;26:82-9.

15. Robinson MD, Robinson LA Jr. What does it mean to be a personal physician? A father's advice to his son. J Am Board Fam Med 2013;26:96-7. 